\title{
Dance as an agency of change in an age of totalitarianism
}

$\mathrm{T}$ his article identifies two different paths where the amnesia described by Hannah Arendt and the fragmentation identified by Willie James Jennings of our historical past has distorted how people today view dancing. I set out how the Christian entanglement with colonial powers has impacted on people's abilities to relate to their bodies, lands and other creatures of the world. I describe how the colonial wound of Western society forms the basis of the loneliness and alienation that totalitarianism inculcates. After this, I examine how people who seek to find a solid tradition of dance within the Western traditions of Christianity often end up in a conundrum when they seek to legitimize the existence of the tradition in the wrong places. I show how seeking roots for Christian dance practices in Jewish customs is often entangled in supersessionist understandings. These arguments are constructed by means of both J. Kameron Carter's writings on race and theology and the black political theology outlined by Vincent W. Lloyd. The second-most-often chosen option for creating a dance tradition for Western forms of Christianity is to romanticize the non-Western 'other'. Using Lindsey Drury's work, I argue that dancers have perpetuated the interests that seek to possess the 'other' by bringing exotic dancers to the Western marketplace. Finally, I describe the third option - more commonly found amongst those critical of Christian tradition - to seek the roots of transformational dance practices in Hellenistic and more esoteric teachings flourishing in the early twentieth century. We run into the often forgotten or neglected stories of renowned dance teachers like Rudolf Laban and Isadora Duncan on this path. By combining esoteric bodily practices, Mother Earth 'spirituality' and superior views about race, they not only promoted but laid the foundation for how people were manipulated in the Third Reich. I end by sharing ethnographic stories of resistance towards how these past historical patterns have affected how dance is viewed today. Those exhibiting such resistance are not always consciously aware of the historical roots I have described. However, engagement in contemplative and healing dance practices seems to be forging new and better ways to create community and to live in a connected way with creation and our creatureliness (Hellsten 2021a). The central theme of these practices is to resist the illusion of perfection and control while helping people to listen to and discern the Holy Spirit leading them into a new way of living.

Hanna Arendt wrote in The Origins of Totalitarianism (1973):

Totalitarian government, like all tyrannies, certainly could not exist without destroying the public realm of life, that is, without destroying, by isolating men, their political capacities. But totalitarian domination as a form of government is new in that it is not content with this isolation and destroys private life as well. It bases itself on loneliness, on the experience of not belonging to the world 
at all, which is among the most radical and desperate experiences of man. (Arendt 1973: 476)

Before a pandemic spread across the world, creating new levels of destruction of human political capacities, the women I have conducted ethnographic fieldwork with spoke about the sense of isolation and loneliness that the current world order brings to Swedish society. Their starting point of dancing may not be the first thing that comes to mind when speaking about political agency and cultural change. ${ }^{1}$ However, as I hope this article will show, theirs is a voice of deep resistance to the isolation and loneliness which Arendt has described as the tools of totalitarianism.

\section{Introduction}

In 2014-16, I conducted participatory ethnographic fieldwork in two different leadership courses linked to the Church of Sweden, where dancing, bodies and movement were central to how people were taught to be leaders in their local communities. ${ }^{2}$ I followed and interviewed eleven

1 I do not intend to equate political agency with cultural change. Instead, I will argue, along the lines of Vincent Lloyd in Black Natural Law (2016: 153-6), that neither politics nor culture has any real agency before it has recognized how human actions are embedded in tradition.

2 One of the leadership courses was named 'Kropp \& rörelse i gudstjänsten' (KR), organized by the Stockholm diocese, Church of Sweden. The other, named 'Livets danser' (LD), is a more traditional 'sacred' circle dance leadership course arranged by a secular 'folk' educational institute. 'KR' and 'LD' signify which leadership course the participant attended. The term 'BI' refers to a background survey made before the leadership courses started, 'EXI' refers to external informants who women that ranged from non-church members and lay participants in local congregational settings to youth leaders, church musicians, deacons and priests who were paid or sponsored by their churches to attend the workshops.

Like Jonas Ideström and Tim Ingold, I not only participated in these leadership course sessions as an observer, but also traced the patterns these women left behind by following many of them 'home' to their local environments, and corresponded with them through diaries, sharing of artwork and choreographies (Ideström 2015). Our interaction created a web of interconnection where we carried each other through many different life situations (Ingold 2011).

Many of the women shared stories with me about feeling neglected, not only by particular leaders in the Church of Sweden, but more generally by a sense of loss at how their dancing was removed from a Christian tradition (EXI S2; EXI S3; LD AI 4; LD AI 1; LD 22.11.2015.4.3.2; KR BI 1; KR BI 7; KR 21.01.2015.3.3.1). In a way somewhat similar to how Ruth Illman speaks about the quest for a tradition with progressive Jews in London, these women asked if there are any deeper spiritual roots to be found to their dancing. This is a quest for finding roots for the practices, but not in dogmatics or specific theological concepts. Instead, it is to see, understand and connect personally meaningful rituals with a

are involved in dance but did not attend the leadership course and 'AI' are in-depth interviews conducted after the course had ended and the fieldwork period was finished. All materials have been completely anonymized in order to protect the people involved. Coding and classification have been carried out using the qualitative research programme NVivo and the material is stored only on the author's personal computer behind password protection. 
larger community and something bigger than themselves (Illman 2018: 1-9, 12830, 141-2).

In this article, I will explore how such connections have been made within dance and traditions of Christianity in the West. Furthermore, I want to show how, sometimes, these traditions enhance the structures of totalitarianism, while at other times they seem to be able to resist the same. ${ }^{3}$ Such an exploration of the capacity of dance to forge political change will arise from sharing the stories of two women, whom I have given the fictive names Abigaile and Deborah. ${ }^{4}$

The article will proceed in two parts. First, I will briefly introduce how dancing in Christian churches in the West is often seen as having highly problematic roots that support totalitarianism structures. In this section, my theoretical framework is informed

3 At the core of this dilemma is Vincent Lloyd's argument that 'A tradition is more than standards of rational justification. It is a community's practices over time, supported by institutions. To be properly raised in a tradition is to become competent in that tradition's practices, to perform them naturally - as second nature. It is also to feel the right feelings, to value the right values, and to reason in the right way' (Lloyd 2016: 154). However, no tradition of Christianity in the West is freed from racialized and supersessionist logic and actions (pp. 21-6). This means that if practitioners of particular dance practices want to find ways to resist the structures of totalitarianism, they first need to identify the intricate patterns by which these same tendencies imbue the traditions they aim to be part of. It is the tension between tradition, community practices, institutions and individual actors in an age of totalitarianism that this article aims to display.

4 None of our meetings were recorded. Instead, the stories are based on my notes from the situation that have then been sent to each woman for a feedback session. not only by Hannah Arendt's work; I draw even more on J. Kameron Carter's, Willie James Jennings's and Vincent Lloyd's racecritical readings of the Christian traditions of theological reflection. Furthermore, I uncover the role esotericism plays in certain bodily practices of education.

In the second part, I will contrast the problems portrayed in the first part of the article with the stories of the dancing women I met. In particular, I counter the lure of a sense of belonging created by supersessionism and 'worldly' charisma with the gifts offered by the Holy Spirit. ${ }^{5}$ I will also argue that when dancers move away from disembodied movement practices and techniques to those that integrate body, mind, emotions and spirit, they will be better equipped to identify and resist totalitarian and colonial tendencies in the tradition. In drawing conclusions, I will suggest how dancing has the potential to reformulate new communities of life and re-imagine our relationship to self and to creation.

\section{Tradition and totalitarianism}

Hanna Arendt spoke, in the opening quotation, of totalitarian governments' aim of destroying the public realm by isolating people from each other and also affecting their private lives. One way in which Arendt describes this process happening is, according to the Arendt specialist Helgard Mahrdt, by historical amnesia. Forgetting our past can take place in a variety of ways. One of these is fragmentation. Mahrdt argues that Arendt - drawing on Walter Benjamin - claims that particularly mar-

5 In this section my main theoretical interlocutor is Barbara A. Holmes, in her Joy Unspeakable: Contemplative Practices of the Black Church (2017). 
ginalized voices need to be wrested from history (Mahrdt 2019). ${ }^{6}$

Willie James Jennings adds that in theological research, fragments are all we have. Fragments of texts, fragments of images, fragments of stories, fragments of experiences and fragments of knowing. These fragments can be seen as a problem, particularly if we want to pose as competent and contained knowers (Jennings 2020: 28-42). For the totalitarian man, two 'secure' paths are presented: it is of utmost importance either to hold the 'truth' by eliminating all opposite stories, or to forge historic consciousness so that people assume history does not 'matter' - we can create our own, new starting-ground and alternative 'reality'. Contrary to these approaches, Jennings remarks:

Fragment in this first sense is a reality of being creatures who can only apprehend with our senses - in bites, in touches, in smells, in sound, and in focused but shifting sight. We live in the reality of these pieces where the world is always too much for us to hold all at once. We creatures live in pieces and we come to know our redemption in pieces. (Jennings 2020: 34 )

As used in this article, totalitarianism is a system that aims to deny this vulnerable state of existence by offering historical amnesia. Either by implying the fear that such an existential precarity may awaken, or by offering a bargaining game of getting rid of these circumstances through presenting 'unquestionable facts' and reality control as the prize, vulnerability is shunned. As I see it, avoiding the fragmented state of life

This conversation can be seen in a fuller extent in Hellsten 2021b: 336-9. arises, for example, when an author asserts with absolute certainty how, where or why people in the past have danced. ${ }^{7}$ Especially when dancing has been a movement in the margins of the accounts of church history, the totalitarian approaches are particularly alluring - offering the illusion of stability and solid grounds for our practices. ${ }^{8}$

As I understand Arendt, the other option is that we are told that what 'actually' happened is either unattainable or only a question of opinions. In that scenario, all memories and shared stories from the past are weighed as equal. ${ }^{9}$ In Jennings's descriptions, as I too will show in more detail below, such a shift in understanding

7 Examples of such totalitarian pleas for a tradition of dance in Western Christendom can be seen in Oesterley 2002 and Grove 1895. Also more recent works like McNeill (1997) argue strongly for dance being rooted in secular views of science and human biology, which is equally problematic. Contrary to these views Vincent Lloyd argues that the one thing that all humans share is an essential ineffability (Lloyd 2016: 158). Thus, for him just as for Jennings both tradition and history cannot be built on anything else than fragmentally grasping towards the unattainable.

8 Contrary to this, Walter Benjamin and Jennings speak about bearing witness to the past by gathering together songs, sounds and stories that will only be an echo of what was. The work of a historian is to find, unearth and hold close. As soon as we think that we may possess, we have erred (Jennings 2020: 35; Hellsten 2021b: 338, fn14).

9 Lloyd explains how it is often asumed that there is a neutral place from where traditions and political actions can be rationally judged. He states: 'the very standards of rationality, of what counts as making sense, are embodied in a tradition, there is not a neutral standpoint from which multiple traditions can be viewed. Such an imagined neutral standpoint, free of all religion and culture, is a fantasy of secularism and multiculturalism' (Lloyd 2016: 155). 


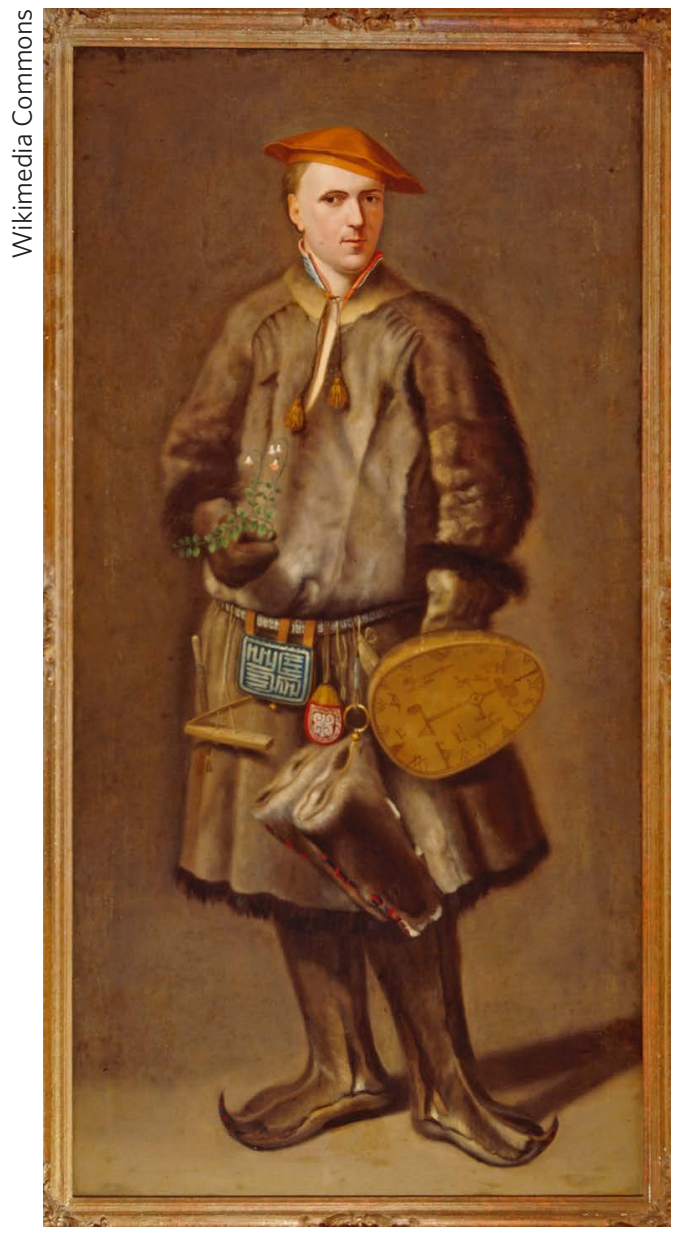

Carl Linnaeus is depicted as the 'discoverer' not only of a system of taxonomy but also a variety of specific species of animals and flora. Here, Martin Hoffman paints him in 1737 under the title: 'Linnaeus in his Lapland dress'. $\mathrm{He}$ is portrayed with various artefacts that belong to the Sámi. The portrait strengthens his image as a conquerer of both the culture and the nature of the regions he visited. In his hand, for example, he holds a flower which has received a Latin name from Linnaeus, while it was actually known and named long before him by the Sámi population living in the territories he visited. Carl Linnaeus is also one of the 'founding fathers' of the taxonomy of humans. He distinguished groups like the Asiaticus, Europaeus, Americanus and Africanus based on skin colour and the regions of the world were these groups of people originated. In later additions he also added the taxon 'monstrosus' for 'wild and mon- is often linked to the commodification of historical artefacts and the communal memories under modern colonial rule. Put briefly, people, places, relationships, artwork and a living tradition of inter-connectedness is ripped apart, forcefully displaced and disconnected both from the life force within them and the bonds that keep the mesh of creation together (Jennings 2020: 41-2; Jennings 2021).

In a dance-history context, the claim that by owning or possessing some part of a thing, one knows it, and by dissecting and assembling things, one can produce them, many aspects of movement rituals have been made irrelevant for theological scrutiny. In these processes, the dances have been stripped of their political power shipped into the boxes of 'primitive' ways of expressing religiosity, 'curiosa' for purposes of entertainment or direct exploitation in the interest of tourist commerce or 'cultural exchange' (Drury 2021: 338-89; Hellsten 2017: 117-36; Hellsten 2021b: 81-8). These are some of the ways that people lured by totalitarianism have contributed to making dance 'meaningless', both personally and politically.

Contrary to these approaches of fragmentation, isolation and historical amnesia, Jennings's starting point of embracing our creatureliness and an incomplete grasp of reality opens up another way to relate to the historical roots of dance and the traditions of dance and theology we have. This is a path of weaving fragments together with the aim of attaining a life lived well

strous humans, unknown groups, and more or less abnormal people'. These distinctions laid the ground for the scientific racialization that dominated later discourses on human development also adapted by the philosopher Immanuel Kant. Museum Boerhaave. . 
together, and this article aims to contribute towards such a healing communion (Jennings 2020: 44). Before we get to this point, it is time to look a little more closely at those practices that concretely hinder dancers from this aim and that have often brought dance into entirely different uses.

\section{The search for a tradition}

When I visit churches and speak about dance, the most commonly heard explanation for why it is OK to dance in a church is that 'Jesus danced'. Often, it is explained further that as he was a Jew, we know that he danced, and sometimes people add references to the wedding feast in Cana as a concrete example. ${ }^{10}$

In the diocese of Turku and Kaarina, in Finland, there is a tradition that can be traced back to the end of the 1980s, where particular congregations or people in the local parishes arrange evenings with 'traditional' Jewish folk dances. On the Finnish Israeli dances website, one can read that many of the groups that gather across Finland are linked either to Christian missionary groups or Jewish cultural associations (Israelilainen tanssi 2021). This material shows that Christians dancing and an idea of Jewish roots to these dances is part of how a tradition is portrayed.

I have written elsewhere about the challenges of what happens when such roots are romanticized. I have also addressed the problematic aspects of establishing a sense of 'authenticity' and historic 'origins' for the Jewish dances taught today by distorting the formation of the Jewish dance tradition (Hellsten 2017: 117-36; Hellsten 2021b:

10 The story of the wedding is found in John 2:1-12, however, nowhere in this text is there any mention of dancing; it is merely presumed that all Jewish weddings historically included dance.
81-101). As I see it, these are tendencies of Christian communities today living in historical amnesia. Fortunately, the Israeli dances website does not portray the history of their practices in these romanticizing ways (Israelilainen tanssi 2021).

However, in this section, I want to address the much more subtle tendency of supersessionism, which has been part of much Christian theological thought and discussion (Lloyd 2011: 2-26). Willie James Jennings starts by describing how supersessionism, crudely put, is thinking that 'the church replaces Israel in the mind and heart of God' (Jennings 2010: 32). Later on, he further develops this notion by showing how Christian identity is placed 'fully within European (white) identity and fully outside the identities of Jews and Muslims' (p. 36). This is the womb where we can find the formation of a racial scale in the Western imagination of the Christian self and the church as a social space (ibid.).

By the end of his book Christian Imagination (2010), Jennings has shown how a transition occurs, where the focus of how people in the West understand the biblical stories is one where white Christians are equated with Jews, and the promised land of Israel is equated with the lands and people that Westerners are conquering. Finally, the special connection between God and his people is now reconfigurated into a love affair with the white Europeans - their languages, traditions and cultures. Those who would have been considered Gentiles in the stories from the New Testament are now uplifted as the chosen people and the 'true' inheritors of a special connection with the divine through Jesus (pp. 140, 167-8, 251, 265).

Jennings brings to the foreground the tendency in Christian communities to place themselves in the centre of the stories of the Torah. The most obvious examples 
of these tendencies are when Jews and Muslims have been shunned as the disinherited 'outsider' of a Christian community - often combined with portraying Jesus himself as a white European male instead of as a person with Middle Eastern origins (Jennings 2010: 33). J. Kameron Carter further brings up how later European philosophers like Immanuel Kant actively worked towards disembodying Jesus from his Jewish flesh. Kant not only stated the need to make Christian wisdom find its roots in Greek philosophy, he even approved of the need to remove the European culture from all 'contamination' of Jewishness. For him, this was particularly linked to what he saw as the problem of Jewish ritualistic and sensual ideologies that ruined the social sphere of human life (Carter 2008: 104-8, 116-17).

I see it taking many different forms in relation to dancing and dance practices in the Christian churches. One of these is when Christian communities want to find their 'roots' in Greek or Gnostic traditions of 'enlightenment' without considering the antisemitic connotations found in those textual traditions. ${ }^{11}$ Often, the romanticization of the Greek tradition with this disembodied element is not easily distinguished from a 'retrieval' of the Platonic aspects of a Christian tradition nor the liberation' of females portrayed in so-called Gnostic teachings (Coakley 2013: 29-30,

11 The examples of this are numerous, ranging from theological accounts like Wetter (1961: 1-12) to the idealization of mystery cults in Mead (2005) and those who have followed his lead. More on this in Hellsten (2021b: 62-3, 66-72, 74-5, 108-10, 127, $157-8,162-4,166-7,169-72)$. On the antisemitism or anti-Judaism found in Gnostic writings see King 2003b; Pagels and King 2007.
104-5, 121-6). At other times, as in the case of certain kinds of esotericism, which I will turn to later, the combination of elitist enlightenment and antisemitic thinking is more than evident but seldom discussed in Western spiritual dance settings. ${ }^{12}$

A second tendency is when dancers in Christian dance groups want to 'spiritualize' their dancing in contrast to the 'fleshly' character of the Jewish dances. Denial of Jewish flesh can take the form of overemphasizing the 'purity' of the Christian dances by referring only to the interiority of the movements. However, it can also be done by over-emphasizing the Jewish dances' supposedly 'folkloric' character or their showing merely cultural traces of a tradition that historically carries spiritual and political significance (Yarber 2011, 2013).

Thirdly, in their centring practices, white Western dancers claim that they are not just picking up but even safeguarding lost traditions or 'ancient' teachings known to the Israelites. The subtle displacement of Jewishness can also happen when Christian communities 'adopt' Jewish dances as Christian or assimilate the stories of the Torah into a thoroughly Christian setting. It is not only when the Jewish tradition is directly neglected, and 'white'-washed that violence is done to the tradition but also as soon as there is an erasure of the dissimilarities between the Christian and Jewish heritage. ${ }^{13}$

12 An exception to this is the critique brought forth against professional dance company leaders and choreographers that work within a Christian framework. For more on this see Schwan (2017: 30); Karina and Kant (2003).

13 Jennings (2010: 167) writes: 'The theological imagination that deploys divine presence without concomitant real presence 
Furthermore, Carter and Jennings tell us that supersessionism, first developed in the relationship of Jews and Christians in the early church, ${ }^{14}$ took utterly new forms when Christians in the West started their colonial endeavours across the world (Carter 2008: 82, 201; Jennings 2010: 31-6). There has been a tendency in the theological traditions of colonial Christianity to place oneself at the forefront of a privileged ethnic group and nation, singled out by God as the 'rulers' of the earth. This is often done by abolishing the Jewish people and land of Israel. Such substitution of the Gentile self with the chosen people has also affected how colonial Christianity

and real relationship may be enacting a form of Gentile hubris that believes we have the right to claim the very reality that was only announced over us by a gracious act of the Holy Spirit in the presence of Jewish believers (Acts 10, 11). Equally important, this adoptionist habit of mind turns peoples toward an isolating theological creativity, imagining the divine among one's own people. Such imagining is not wholly wrong, but it is impoverishing. And Christian theology in modern times has been set in place by this very poverty. So the gospel transmitted means in many imaginations the ways in which different peoples have culturally adopted and adapted Christian faith, ideas, doctrine, and language. Unfortunately, the universal (bound up in docetism) and the contextual (bound up in adoptionism) are currently the dominant options for the contemporary theological imagination. They are two sides of the same coin, the one enabling the other, and neither finding its way to a Christian theology that of necessity creates intimacy.'

14 Karen L. King (2003a: 40) explains that 'the orthodoxy that developed in the fourth and fifth centuries was supersessionist by definition, and provided a basis for the gravely problematic dogma that God had rejected the particularism and literalism of Judaism in favor of Christianity's universal salvation and allegorical interpretation of Scripture'. has met and dealt with indigenous people, non-white bodies and the rhetorical use of 'pagan' as a category of those unable to live in intimate relationships with God (Jennings 2010: 97-8, 101-2).

Jennings explains a process that started with the Europeans making sense of converted Moors and Jews on the Iberian Peninsula and ended with a hierarchical pattern where some races were considered 'brutish' and animalistic to the point that they were excluded from the capacity to become Christians. ${ }^{15}$ Often such evaluation hinged on the idea of a superior gaze attained only by the white, male, theologically schooled Christian, who could distinguish not just between 'blood' or races, but aesthetic and cultural features that became what Jennings calls 'ontic markers' of civilization (Jennings 2010: 31-6). The closer to whiteness you were, the closer to the possibility of salvation and becoming a proper member of society.

Disturbingly, the colonial gaze went beyond the 'surface' features described here. At a later stage, it also started to penetrate the 'interior' parts of the human. Through the writings of José de Acosta (c. 15401600), Jennings shows how discerning demonic activity became another way by which the Europeans expanded their power to rule. Now, the schooled theologian could

15 Jennings uses the writings of the Jesuit father, José de Acosta's (c. 1540-1600), De procuranda Indorum salute: Pacificación y colonización, to show how he systematically organized people in the following way: 'The third class of barbarian are those peoples who live like wild animals, hunting and gathering in packs and having no governmental sensibility or system of writing. They "hardly have human feelings-without law, without agreements, without government, without nationhood, who move from place to place".' (Jennings 2010: 102) 
judge possession within individuals and demonic influence in certain types of 'religious consciousness' where larger groups of people gathered (Jennings 2010: 95-6, 103).

All of this relates to questions of dance in the more obvious way, in that the markers of 'brutish' behaviour came to be acts of dancing, leaping and bodily rituals that involved immersion in nature and connections with the land (Jennings 2010: 31-4, 37-9, 95-6). Kelina Gotman, in her Choreomania (2018), fully develops how the idea of particularly frenzied dancing came to be connected with the colonial and hysterical body. Also resistance towards ritualized and festive dancing came to be seen as political and social threats to the ordered civil society of Western governments. Through these new patterns of how Christian bodies move and behave, ideas about Westerners' bodies and the range of movements for white bodies in the European context were restricted, fractured and changed. These are some of the patterns of how the structures of totalitarianism - rooted in colonial practices visibly started to affect the movement of bodies in both private and public space.

What might be a less obvious consequence of these historical developments for dancing in churches in the modern period is the more subtle aspect of how the selfunderstanding of 'Christian' has shifted through the centuries. Through the distorting gaze of the colonial imagination, an erasure of the memories of how pre-colonial Europeans used their bodies, rituals and movement in social settings for spiritual and political purposes was accomplished. A new 'ideal' about the Christian community is developed - one that sits still, reads texts and carries on with intellectual debates - and the history of dancing in churches is forgotten. ${ }^{16}$ To clarify, what I have been arguing here is that what was developed in the processes described by Jennings and Carter is a disembodied tradition of Christianity.

Furthermore, Vincent Lloyd argues that current states of supersessionism in political theology take the following forms. There is a tendency to presume two separate spheres of 'reality' - the immanent and transcendent, the 'spiritual' and 'earthly', secular and religious. These are then, in theological discussion, superimposed on the world we inhabit. He describes the tendency to not just polarize such spheres. We are also asked to choose one of these spheres before the other. Furthermore, different schools will project hope onto one of these spheres for it containing the needed tools of liberation of humans from their suffering. This can take various forms; however, at the core is the separation of one from the other instead of staying with the messiness of the lived experiences (Lloyd 2011: 2-26). He explains:

Avatars of supersessionist logic bring with them melancholia. Fixation on a lost object makes the existing world appear in shades of gray. The fixation never loosens. In fact, it tightens when it is coupled with hope: fixation on a lost object in the past is maintained by projection of a desired object into the future. (Lloyd 2011: 15)

When describing a tradition of dance in the Christian churches of the Latin West,

16 For more on the religious roles of dancing in medival Europe see Dickason (2020) and Hellsten (2021b), and on the shift in the understanding of religion and particularly understanding the role of theological work in universities see Harrison (2001). 


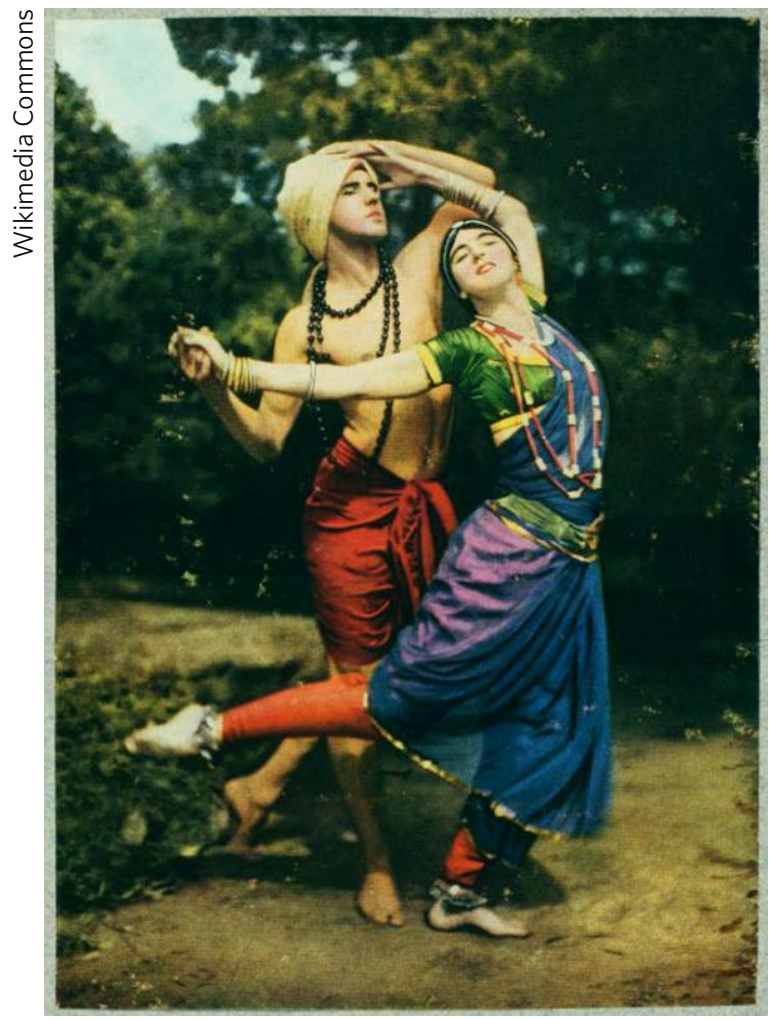

Ruth St Denis and Ted Shawn in a photo taken outside, in costumes that carry clear signs of orientalism. Photo by Franklin Price Knott for National Geographic Magazine, April 1916, reprinted May 1951.

this form of supersessionism is perhaps the most evident. Christian dance is either described as wholly 'sacred' or secular (Dickason 2020). It is distinguished from the supposedly pagan or Jewish dances by being more 'spiritual'. Finally, when dancing is given room in the body of works of 'orthodox' Christian traditions, it is portrayed as aiming at complete transcendence (Hellsten 2021b: 142-62).

Some of these tendencies I have already touched upon. Unfortunately, much theological thinking, even when aiming to resist the colonially distorted ideas about dancing, spirituality and 'primitive' forms of religion, still falls prey to this subtle racializing imaginary. To this, I will turn next.

\section{Resisting the forgotten tradition of bodily practices}

Even those dancers who believe they have left the idealization of a Christian or Jewish heritage behind them are still often caught up in their Western cultural upbringing - either romanticizing or claiming direct possession of spiritual practices not part of their heritage. Today, we may call this cultural appropriation (Thomas 2021: 275-90).

Jennings explains that the generalizing and universalizing tendencies and the claims of access to other peoples' traditions and cultural practices are all aspects of how the colonial gaze erroneously thinks it can penetrate through the particularities of bodies, cultures and lands. In creating structures of 'sameness' and likeness the European white hegemonic superiority is only reconfiguring itself into academic knowledge and educational practices (Jennings 2010: 139, 147, 160-1; Jennings 2021). These tendencies can also be seen through the development of dancing and dance traditions in the late nineteenth century.

In the more professional and later commercial world of white dancers, one individual after another in the early twentieth century started to claim that they had gained knowledge of or found access to the authentic movements in ancient cultures, 'pagan' dances and mystery cults. Sometimes this quest was directed towards Greek antiquity, such as Isadora Duncan's work. At other times, the shows and practices were built around displaying indigenous traditions, as in the case of Ted Shawn. Both the professional dance scenes and more private spiritual seances portrayed exoticization and eroticization of the Orient, as seen in the repertoire of Ruth St Denis and Shawn (Drury 2021: 367-76). These movements have their particular mechanisms and 
internal developments, which I do not aim to discuss here. In this last section before the second part of the article, I want to show how the cultural tendencies described above are not just part of romanticizing the 'other' or resisting a 'lost' tradition of spiritual dance. They in themselves too often become agents of destruction.

In many of the dance circles I took part in during my ethnographic fieldwork, an outspoken criticism of the patriarchal structures of the church could be found. Now and then, the lack of dancing in congregations was associated with the idea of suppressing the feminine or even the witch hunts of the past (KR 19.08.2014.1.2.3;
KR 22.10.2014.2.3.1; KR 10.12.2015.6.1.2; LD P2 Abigalie; LD P1 Batshemath; LD 06.09.2015.3.4.1; LD 21.11.2014.4.2.0). In contrast, language around 'Mother Earth' and the feminine divine was bountiful. The idea that we need to listen to our bodies and emotions, getting in contact with a 'hidden wisdom' within, was very much part of every exercise we did. At times, discussions of esoteric and mystical traditions were brought forth as relevant teaching on the body and how dancing may harbour more healing properties (LD 05.09.2015.3.3.0; KR 26.01.2016.7.2.1).

Simultaneously, spiritual dance practices that resist the legacies of colonial

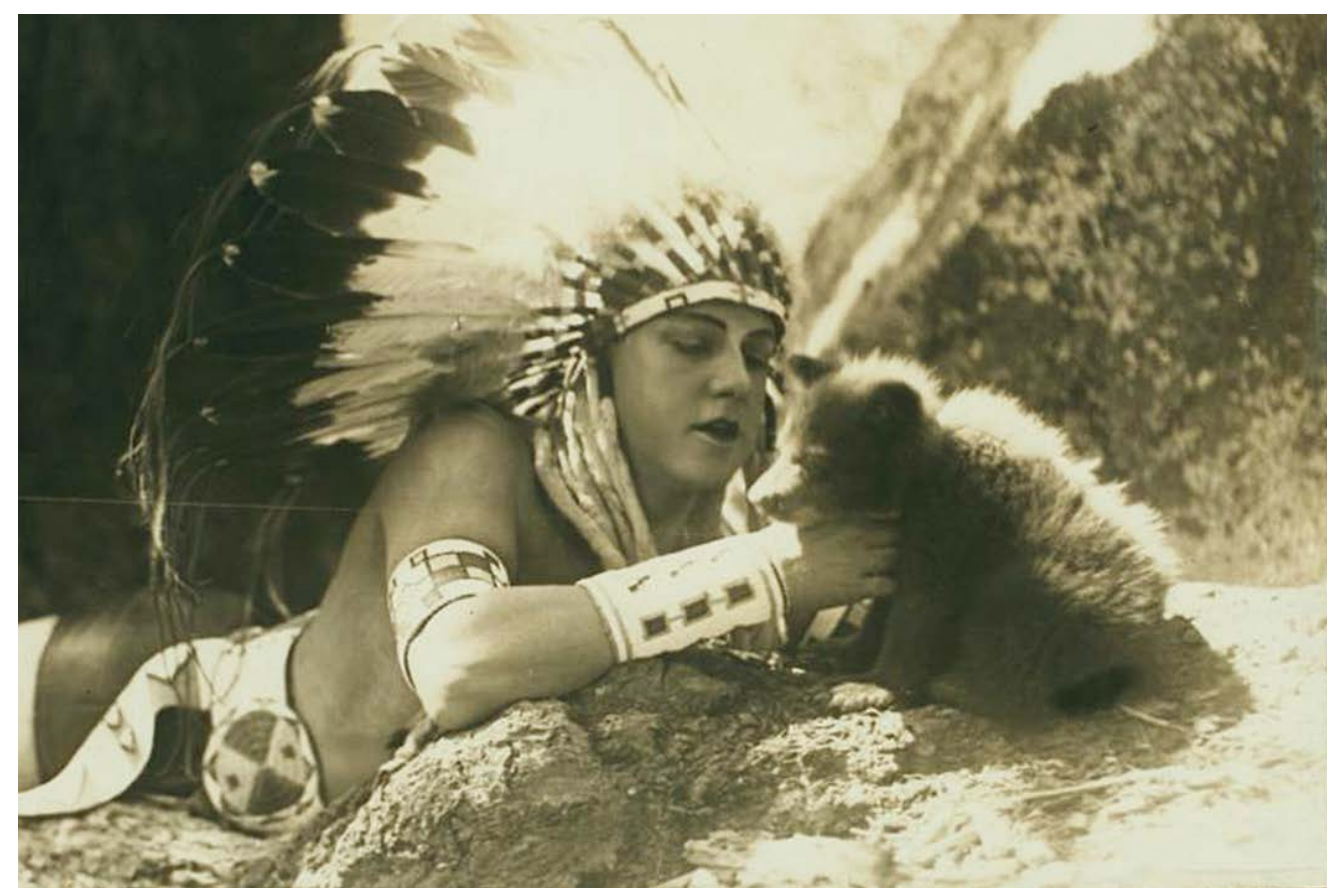

Ted Shawn even ventured into wearing headdresses that among the indigenous populations on Turtle Island are only given to respected and distinguished members of the tribe. A headdress was used at special occasions and in religious rituals - not as a prompt for costumes. In this image Ted Shawn was photographed in Yosemite National Park in 1921 with a bear cub, to give an 'authentic' feel to his new piece Invocation to the Thunderbird, that worked with the idea of a prayer ritual in the wilderness. According to Jane Sherman (1989: 369-70) Invocation to the Thunderbird was set to music by John Philip Sousa from his suite Dwellers in the Western World. Created in 1917 as a class exercise dance, it was added to the Denishawn repertory in 1921 and remained one of the most popular numbers for years. Denishawn Collection no. 661-770, New York Public Library Digital Collections. 
Christianity often idealize leading female dance figures, such as Isadora Duncan or Ruth St Denis (Adams and ApostolosCappadona 2001: 109-51). As in the dance practice I am trained in - Nia these dancers are portrayed as liberators of women from the oppressive structures of classical ballet or restrictive movements into more child-like gestures and empowering paths of freedom. ${ }^{17}$ What is often ignored or maybe wholly unknown is the fact that many of these individuals not only resisted the church practices of their time, but were instead profoundly involved in the theosophic teaching of Helena Petrovna Blavatsky (1831-91) (Antonen and Kokkinen 2020: 54-67).

In Hitler's Dancers (2004), Lilian Karina and Marion Kant explain how Blavatsky's

17 Also, the writings of Kimerer LaMothe $(2006,2018)$ continuously aim to emphasize that Isadora Duncan's primary impulse in creating her approach to dance was to find a way to release the individuality of every human body. Similarly, for Ruth St Denis, a case can be made that her intention was liberation - to show the Western colonial world that the dances of other religions were both art and religion, and not just uncivilized, backward activities that white Christians should dismiss. Even though I fully agree with the anonymous reviewer of this article that no practice can be declared wholly totalitarian or as freeing individuals from patriarchal and colonial rule, I do not agree that the intentions of these dancers are enough to 'purify' their goal. Most of all, for the argument I am making here, it is precisely the intention that Duncan has of liberating the 'soul' and the idea of St Denis to be able to create a 'new' religion of dance that are the core techniques by which their supersessionist logics become so clear. Vincent Lloyd has clarified this by showing that we cannot step 'outside' the tradition and the norms to create opposition to the norm - this is a supersessionist illusion (Lloyd 2011: 23-4; Lloyd 2016: 155). teachings were not just occult and esoteric in the usual manner of these times but held deep convictions about the superiority of the 'Aryan' race and how white people should use their bodies to develop into the new leaders of the earth. This is one of the reasons why Rudolf Steiner, at an early age, parted ways with Blavatsky. Instead, he developed his schools of anthroposophy and the dance therapy of eurythmics, which grew out of these teachings (Karina and Kant 2003: 30-1).

Karina and Kant give a thorough description of Isadora Duncan's and later her sister Elizabeth's outspokenness about their antisemitic and anti-black judgements and their 'eugenic' aim of eliminating all individuals not fitting their 'national' standard. Elizabeth Duncan described their dance schools for girls as part of a national programme to develop the 'perfect' race. White women were trained through dance, gymnastics and callisthenics to become the promulgators of the Greek postures and developers of the 'Nordic' rites of purity. They were encouraged to connect the German 'spirit' with the German soil as steps towards forming the 'deepest essence of womanhood' (Karina and Kant 2003: $32-7,62-4,76,267)$.

In the Third Reich, modern dance teachers and practitioners from different sides of the 'expressionist' dance movement (Ausdruckstanz), together with the associations of social and folk dance, were more than eager to 'finally' rise above the classical ballet and take centre stage in serving the needs of the new nation. This was done by 'cleansing' the dance schools of unwanted elements (students and teachers had to give accounts of their heritage) and forming the movement practices and choreographies that would create the new citizens. Leading figures like Rudolf von Laban, Gret Palucca and Mary Wigman set out to 


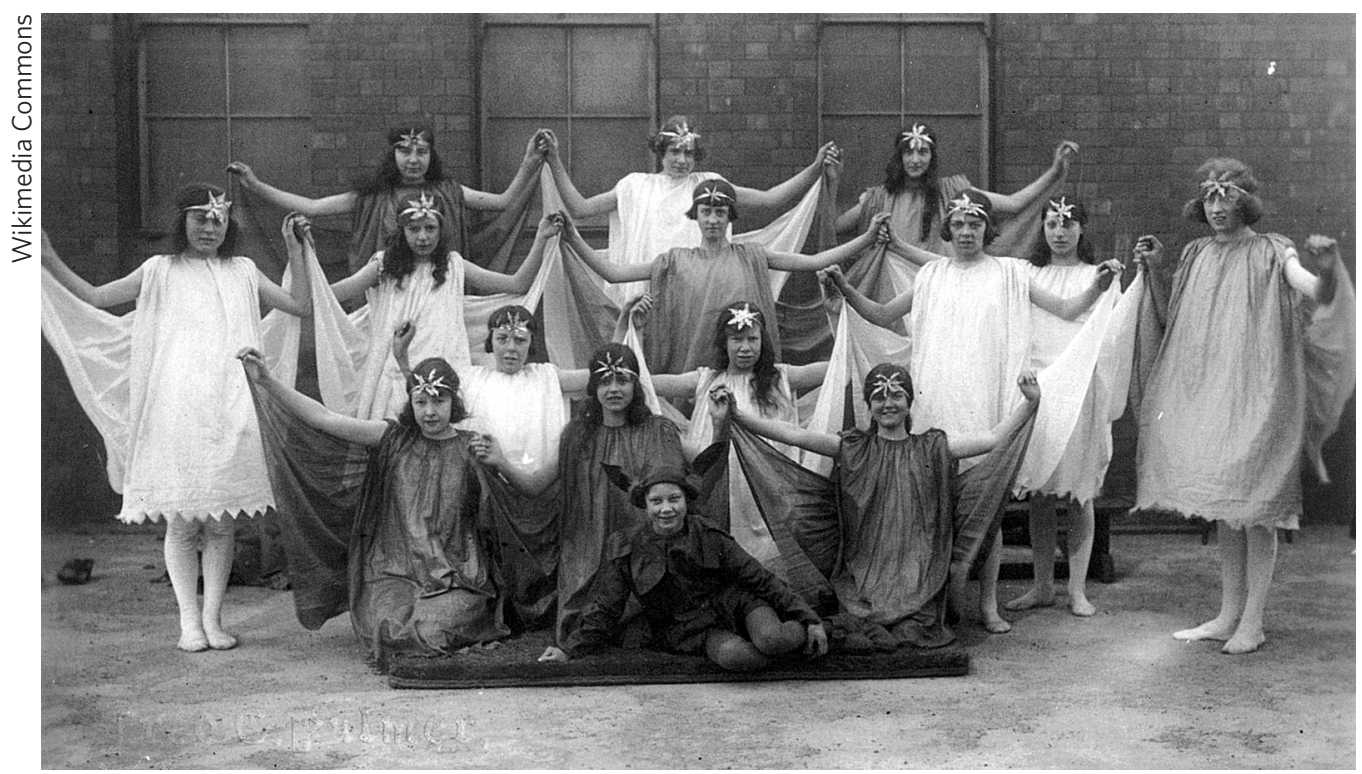

Postcard photo of schoolgirls dressed for Greek dancing, in or near Swindon, Wiltshire, England. From the 1920s to around the 1960s numerous girls' schools in the UK taught Greek dancing in the manner of Isadora Duncan. The girls had to wear cotton fabric costumes cut from a pattern designed by Duncan, in a selection of pastel colours as worn by her dancers. The dance movements imitated some of the female poses exactly as seen on ancient Greek vases. This included walking sideways with body facing forward, as depicted on the ancient urns. This dancing style was favoured by schools, which hoped to improve the deportment and posture of pupils. The countryside themes of Greek dancing may be reflected here by the costume of the seated girl at the front. Greek dancing in the tradition of Isadora Duncan was usually performed in bare feet, although these girls may be wearing shoes. Photo by Fred C. Palmer of Tower Studio, Herne Bay, Kent, c. 1905-16. .

develop programmes for the formation of the gestures and habitus of the 'true type' to be practised in youth movements and dance studios, as well as for deciding which kinds of plays and performances were to be put on stage. They sought and found the approval of the state officials so that these could use bodily knowledge and esoteric teachings for party purposes. Teachers of dance were central actors who lay behind public events, such as the Olympic Games of 1936 (Karina and Kant 2003: 16-21, 23-9, 37-8, 85-96, 114-35).

Even though both Laban and Wigman later fell out of popularity, their influence on the practices of Nazi Germany and later teaching on bodily technique are very much interconnected. What is even more disturbing is, according to Karina and Kant, that Laban and Wigman did not fall out of popularity because their opinions had changed. Instead, what may have seemed 'murky, blurry, apparently impressive metaphysical nonsense' (Karina and Kant 2003: 91-2) about how to unify people through movement, and finding the healing energies of feminine and masculine powers though dance, were tools too powerful for the leading party officials to set to one side (pp. 90-4, 124-35). The German politician and author Hermann Rauschning in Gespräche mit Hitler (1940) is said to have stated about freemasonry: 
Do you not see that our party must become something very similar? An order, the hierachical structure of a worldly priesthood, but that means naturally that there can be nothing like it on the other side. It is either us or the freemason or the church. (Karina and Kant 2003: 32-3)

These examples show that the tools of totalitarianism did not only extend to distorting the fragmented pieces of the historical past to create an alternative history of lost greatness that now was to be regained; there was also a clear agenda of giving people a new sense of community by incorporating their bodies and spiritual practices into a felt sense of personal power and communal agency. Notably, Kant points out that this process was done by taking physical movements and creating public manifestations. However, the most crucial element may have been the constant reminder that these gestures were to be combined not with thinking but with strong feelings and a willingness to be moved. Laban shuns anything related to 'intellectuals' and states that rationality and reasoning are harmful and damaging (Karina and Kant 2003: 126).

What is shown, I believe, in these esoteric dance practices - that claim to break free from the patriarchal church tradition and find roots in ancient mystery cults - is the supersessionist tendency to dichotomize and spiritualize. Through nostalgia for the past, people are brought into an area of grey, where they lose touch with actual history and their inner selves. By forging strict lines between body and mind, emotions and reason, state and church, and aligning with the 'art' chosen to portray the party politics, what occurs is a hollowing out of the power of dance. Instead of being a force of resistance, it becomes a practice of manipulation.

\section{Stories of dance}

It is now time to turn away from the past and listen to the stories of Abigaile and Deborah. Essential to an understanding of their background is that Abigaile does not consider herself a member of the church and does not speak of herself as a Christian, while, on the other hand, Deborah is an active member of a local congregation and employed by the church of Sweden to take care of specific tasks in that setting. Still, both participated in the leadership training to become instructors in the 'sacred' circle dance tradition. In these stories, they shared their dreams, hopes and struggles with dance freely with me.

Let us start with Abigaile:

One day I wish that we could be dancing - openly in a public space out on the square of a city centre with people from different cultures, nations, traditions and places. Creating a space where despite differences, people would come together, but also humans with animals and nature. In these kinds of true communities creativity could flow and healing happen.

She described a sense of connectedness that was not linked to a church or even the term Christianity. It was not that dancing in churches or communities of Christians did not provide such a space - it was amongst them she had found circle dancing. Also, importantly, one did not need to pay for dancing in churches. Rather, what she wanted to stress was that she had been to circle-dance gatherings in churches where this sense of connection or even the Holy Spirit was missing. So, the experience of healing and community that could be sensed in circle dancing was not bound to the form itself. The last time she went dan- 
cing in a church, her experience was that the dancing there, in that group or just on that specific occasion, had turned cold - it was empty technique, no life-force. What was missing was the Joy with a big J. The connection, the sense of being part of something whole and more expansive. 'I am still dreaming of finding this community and reconnecting with this kind of unity', she said.

Abigaile explained that one of the things she appreciated with the dancing in churches was that it did not cost anything. There was no commercial gain to be made out of bringing people together nor from helping them find healing and connection through movement. ${ }^{18}$ She also spoke about the sense of community that could be gained when people came together in a certain way.

An essential element in this community was that it brought forth healing. As I understand it, there was an openness towards the fragmented way of existence. Healing took place not only between or within humans; ${ }^{19}$ like Jennings, she spoke about embracing our creatureliness - bringing different kinds of people and animals together into a connection with nature. Contrary to the idealizations of Isadora Duncan, this is not an erasure of differences and striving for some kind of perfection and similarity in bodily form. Instead, Abigaile speaks about

18 Consumer spirituality does exist in the Church of Sweden. However, the financial structures of the Nordic Lutheran churches are quite different from those of many other places. Thus, traditional American capitalist Christianity does not have a massive hold on organizing retreats and dance retreats, prayer and dance events etc.

19 More on the healing aspects of the dancers experiences in Hellsten (2021b: 117-34). the importance of joining together in our dissimilarities or distinctions.

From a theological point of view, what is interesting is that she vocalizes a unity to be found in or through the Holy Spirit. ${ }^{20}$ Furthermore, as some of the teachings on xapá (chara, joy) - which the Holy Spirit may bring - emphasize, Abigaile experiences that joy is a signal of the presence of the Holy Spirit (Tronca 2016: 55-6, 60; Tronca 2017: 440-4). The way Abigaile explains it, she is not just able to sense - in her body - when the Spirit is present, she also explains that too much focus on the rigidity of form and technique drives this sense of presence away.

As I understand this, Joy is here something much more than a feeling. We are not speaking of the 'charisma' of a leader that can persuade people to follow in specific ways (Lloyd 2018). Instead, what is described is a more profound sense of lifeforce that flows in the space and between the creatures in it. Barbara A. Holmes speaks about how a congregation may give itself over to a contemplative listening and being, which then will stir the presence of 'joy unspeakable' (Holmes 2017). Distinguishing what may be happening here from the earlier historical examples is a vital element in understanding when dance is in the service of totalitarian forces and when it may be part of a movement towards political change. With the next story, I will develop how I see Abigaile as differentiating between these similar, albeit different, perspectives.

When she speaks about different dance practices she says:

20 Theologically speaking the Holy Spirit offers unity that keeps the distinction and does not bring conformity (Jennings 2020: 135-55; Coakley 2013). 
Previous dance practices that I have been part of are at the core of my being. Like a strong and old oak tree where the roots go deep into the ground. The personal growth and healing that happened when I went into the therapeutic and psychological processes were truly spiritual experiences. Sometimes they further contained an ecstatic/ strong transformational experience. An awakening.

At first, I was a little bit surprised by the circle-dance tradition as it did not create space for this kind of deep transformation by keeping silence and emphasizing the importance of being present for the processes of self and others.

Circle dancing is rather like a willow tree - the marks in the ground are not so sharp or deep. However, what it does teach us is an ongoing continuous connection - the deeper source of joy that will carry us through in everyday life. This is the slow and steady practice that brings all kinds of people together - when repeated continuously like a prayer-practice the circle dance also offers the opportunity not just to unite people but to transform space.

In this second part, where Abigaile compares other dance practices that she has taken part in, she speaks about the experience of being transformed and even being ecstatically touched so that something shifts within her. Ecstasy in connection with being moved by the Holy Spirit can and has been part of Christian traditions as well (Coakley 2013: 116-35, 181, 295, 310, 314-22). Holmes also brings forth the contemplative practices of the black church such as the ring shouts and intensive drum dancing - that display much more ecstatic forms of movement (Holmes 2017: 18-21, $38-42,60-2)$. However, she simultaneously states that it is essential to notice the difference between those touched by the Holy Spirit and those who try to control similar actions (pp. 5-9).

When Abigaile speaks about the Holy Spirit in circle-dance practices, it is much more in line with the 'gentle whisper' than the abrupt events described by Paul. ${ }^{21}$ Also, Holmes returns to the required kind of listening and the patience of waiting that is often involved before the Joy may arrive (2017: 73-5, 79-81). Most importantly, she emphasizes that healing is a communal event, defying any false dichotomies. There will be no distinction between sacred and secular, just as contemplation and social activism are part and parcel of the same change (pp. 113-15).

Interestingly, the image Abigaile uses for therapeutic dancing is an old oak tree. She did speak about her previous dance practices offering deep transformation, but we do not know if this is an individual or a communal experience. Now, however, when she had been deeply rooted in body-centered healing modalities, she could relate to how the circle-dance tradition brought healing to the larger community. She found that the Spirit is present and carries people along even when they do not submit to the format of silence and a strong emphasis on awareness: which other modalities had taught her. While she had been perplexed initially, she was now finding that something about the accessibility

21 In Christian circles, textual passages that indicate the presence of God and how the Holy Spirit may be perceived range from 1 Kings 19:11-13, where God comes to Elijah in a gentle whisper, to Paul's statement in 2 Corinthians 12 that someone was transported out of their body to receive God. 
and steadiness of this form made it not just pliable like a willow tree but open to a larger community and bridging of earlier practices. She had learnt that the experience of Joy itself was something that could be continuously present and that there was no need to seek the ecstasies that had previously defined an extraordinary event for her. She was now speaking about the necessity of living in ongoing devotion and choosing a format that sanctified space as much as the different creatures moving within it. Dancing connected her to these rhythms, and now she just wished that more people would join the dance.

In the words of Vincent Lloyd, what I see at work here is liturgy, a lifetime of sanctity and an event of revelation. Contrary to revolution and revolt, he states that these three are the only things that may complicate our relationship to norms and a tradition so that politically potent possibilities emerge (Lloyd 2011: 24). Along these lines, what I see as happening in Abigaile's example may be participation in liturgical dance, learning a practice that sustains a lifetime of sanctification and the capacity to distinguish a revelatory event. ${ }^{22}$

In Deborah's story, many similar themes arise from a slightly different angle:

I can see it with my ladies. It is important that we dance in a way where the women are allowed to be themselves, just as they are. Sometimes we just practise and at other times we hold a small service of worship. I always start each get-together with a small prayer. It is spoken only internally, yet I invite the Holy Spirit to be present, and I can sense the difference! I know it sounds simplistic, but that is how I experience

22 There is not enough room here to develop the aspect of liturgy to its full potential. it. As soon as I invite the Holy Spirit to be there with us - it is there, that something extra!

I further remind everyone that although it is a practice session we have nonetheless gathered together for a purpose: to listen to, and be with, God. We then take time at the beginning of the circle to sense our own body and heighten our awareness of the here and now.

Once there were some younger women present, I noticed that they wanted more of the silence and a more meditative pace. Simultaneously, I am aware of the importance for my ladies of being able to share and be real and not to be so serious about their spirituality.

I notice this especially when the priest visits us. As soon as the priest is there, my ladies start to fumble and step on each other's toes. I also get distracted and the whole thing moves up into our heads and becomes so focused on the words. Much of that, of course, has to do with the priest choosing not to take part in the dance, and only coming there partly to 'inspect' and officially to hold the service. My experience is that it is as if this formality drives the Holy Spirit away, and I cannot sense the flow. My intuition on how to lead and listen to what the group needs and how to proceed also disappears. My preference is to do the services alone or with a musician so we can keep it on the level where it is alive and authentic.

The times we apparently gather 'only' for practice are no less important in any way. The ladies have told me that they appreciate it and I know they need these sessions where they are led into the how. The how can be dem- 
onstrated to them by means of sharing the meaning of different symbols or giving insight into a Bible passage or the text of the song. This is done so that the ladies get to both experience and practise what it can mean to listen to God. What they get to share is how God can speak to us in the mundane small things and not only when somebody says 'let us pray' or 'this is the word of God'.

Deborah, just like Abigaile, speaks about the importance of the Holy Spirit, and she differentiates dancing from other modalities of spirituality. While she can recognize that particularly younger people have been accustomed to the idea that spirituality is linked to silence and keeping a sense of rigour around how one moves and acts, which stands in contrast to how her ladies meet, she still sticks to the practice. As I understood Deborah, it is not just a sense of differences in taste or preferences. She actually finds some of the more perfectionistic and highly commercialized forms of spirituality creating more burdens. In dancing, the question is not about self-help structures where we climb achievement ladders. The task is instead to learn to listen - again, listening to a subtle voice - and to relax into the ability to be carried by the community. In contrast to how I read pioneers of dance, such as Isadora Duncan or Ruth St Denis, there is no way to control or forge an esoteric connection by using rigorous technique or patterned processes of change.

Deborah offers critical statements on what happens to the Holy Spirit, or rather, the ability of people to listen to and trust the guidance of the Holy Spirit when too much rigour is present. In her story, it is not just the rigidity of formality that quenches the Spirit; it is the tradition of Christianity that has lost its connection with the body and overemphasizes words, which brings stagnation to their worship. In her experience, it is the suspicious representatives of the church - living according to colonial patterns of Christianity where movements do not flow from the core of their being who, when they emerge, bring a 'structure' where the congregation loses its flow and starts to fumble.

Furthermore, Deborah is teaching her ladies the practical application of what it means when communities stop following totalizing voices of compliance and instead start to hear the voice of a life-giving path that is not always easy to follow.

She continues on this topic by explaining:

I could see and sense it very clearly when we had the pilgrimage day with dances. Already in the bus I told them that I had asked for the Holy Spirit to guide us through the day - I know they looked at me oddly - but this is what the Church does too. We are the ones that say and teach that God is present, everywhere. We show this in what we do, in how we listen and notice! Once we got off the bus I explained that when we walked we would do so in silence.

When we stopped at a beautiful spot, I then led them into a dance, gave them a word or an image, after which we would continue walking in silence.

I have been on many kinds of pilgrimage walks, but had not experienced anything like this. The dances were what held the pilgrimage together. They were the precise activity needed for people to stay present. I noticed how my ladies had grown. They were able to be still, to stand there in their own self, to be con- 
nected and know how to listen and what to listen to/for.

The new practice of the pilgrimage walk was to learn how to trust and be led; to allow all kinds of control to fall off - not knowing what would come next - yet be willing to follow the lead. With no ability to plan or foresee the next step a new kind of listening to how God leads opened up.

In this, it was as if the dances became the places of relaxation; they were the 'known' - the pearls that bound the whole walk together. The dances were the tangible places of rest. In their materiality they opened up what otherwise would have become too 'ethereal'.

From one point of view, speaking about the willingness to be led might sound frighteningly close to what totalitarian leaders would want us to do. However, as Willie James Jennings writes, the body that has been shown to a congregation willing to follow a resurrected Jesus opens a path of great risk (Jennings 2010: 273). Similarly, both Barbara A. Holmes and Vincent Lloyd speak of how walking the path of political transformation - even when practices of joy, dance, music and poetry-making may guide our steps - will not mean that we can ever rest assured that we have 'arrived', that we have completed change (Lloyd 2016: 158; Holmes 2017: 183-98). We may only take small steps towards something better, and they often lead to others looking weirdly at us.

I hope this article has shown, however, that there is a path that we can start following. This path starts from a recognition of the past and bringing to the forefront the patterns of what has isolated people, brought them loneliness and hindered them from dancing.

\section{Conclusion}

I have described the kind of colonial wounds that remove dancers in the Christian traditions of the West today, not only from their own bodies but also from the capacity to connect with other bodies, either because they have inherited a story that tells them how problematic it is to dance and connect dancing to their spiritual practices or ritual understanding of living with God, or, as I see it, because they are seeking for the roots and fragmented memories of historical dancing in places that lead them to disembodied and 'spiritualized' forms of dance or to a pattern that violently overtakes traditions and practices that are not theirs to use nor even to borrow.

I have also shown how dancing offers the opportunity to bring together people, lands and creatures without erasing their unique qualities of being in the world. This political power of dance can, however, be distorted when people who are disconnected from themselves are brought to a euphoric state of being, which resembles the ecstasy of spirit. Such manipulation is what Arendt warns people of when we let totalitarian states separate people from each other in the public space and alienate them from their 'inner' selves by making their contributions to the world meaningless. ${ }^{23}$ In such circumstances people become extra vulnerable to manipulation that wants to offer something that seems to make them more 'alive'. At the same time, this article has shown how the process of disconnection between our creatureliness and creation is strongly linked to the colonial and racialized structures of Western

23 In The Origins of Totalitarianism Arendt brings forth her distinction between Homo faber and Animal laborans which describes this point (Arendt 1973: 474). 
Christianity. Our communities are in deep need of healing, and sometimes dance practices may offer such reconnection, patterns for sanctification and communal spaces for liturgical transformation.

The dancers I encountered attempt to re-establish intimacy with self, others and creation, sometimes even more directly aiming at healing past patterns of wounding. This is done by teaching people how to discern the voice of the Holy Spirit in their bodies, minds, emotions and spirits. To give up the self-sufficiency of white European colonial ideals is to give way to an entirely new kind of dependence on each other, on the creation that we have been given to safeguard, and on the kinship relations that exist between all created beings. In Jennings's words, the path where we can find new intimacy and the new citizenship of breathtaking embrace, where different cultures enfold each other to create a new space of communion, is only found where the Spirit pronounces it. An essential task is thus for the Church to teach its members how to listen to the Holy Spirit's calling and learn to see how God's love unfolds. Both Abigaile's and Deborah's stories show that, through their practice of dancing, they are well equipped to follow such a path.

Laura Hellsten is a postdoctoral fellow in ethics and science communication in the Stiftelsen Åbo Akademi Centre of Excellence BACE. In this transdisciplinary research group she ethnographically studies a group of researchers that work with cell communication. She also leads the project

'Forcing the Impossible - Avtryck i det okända', which brings together artists and researchers on the theme of science communication. These collaborations have created both artworks and articles on the importance of science and arts collaborations. She has further written articles on current and historical practices of dance in Western Christian theological traditions. Her doctoral thesis, Through the Bone and Marrow: Re-examining Theological Encounters with Dance in Medieval Europe, was awarded the research prize of the Donner Institute in 2021 and published by Brepols. Together with Nicole des Bouvrie, she has led the study circle on feminist philosophy 2019-22 at the Nordic Summer University. She furthermore always refers to her cat Moses as being one of the most important teachers of theology in her current life situation.

\section{References}

Adams, Doug, and Diane Apostolos-Cappadona. 2001. Dance as Religious Studies (Eugene, OR: Wipf and Stock Publishers).

Antonen, Erkki, and Nina Kokkinen. 2020. Spritual Treasures: Esotericism in the Finnish Art World 1890-1950 (Helsinki: Parvs).

Arendt, Hannah. 1973. The Origins of Totalitarianism (New York: Harcourt Brace \& Company).

Carter, J. Kameron. 2008. Race: A Theological Account (New York: Oxford University Press).

Coakley, Sarah. 2013. God, Sexuality, and the Self: An Essay 'On the Trinity' (New York: Cambridge University Press).

Dickason, Kathryn. 2020. Ringleaders of Redemption: How Medieval Dance Became Sacred (New York: Oxford University Press).

Drury, Lindsey. 2021. 'The double life of "pagan dance": indigenous rituality, early modern dance, and the language of US newspapers', European Journal of Theatre and Performance 3: 338-89, <https://journal.eastap. com/wp-content/uploads/sites/2/2021/o9/ EASTAP_JOURNAL_ISSUE3_sept_2021. pdf $>$.

Gotman, Kélina. 2018. Choreomania (New York: Oxford University Press).

Grove, Mrs Lilly. 1895. Dancing (London: The Badminton Library of Sports and Pastimes).

Harrison, Peter. 2001. The Bible, Protestantism, and the Rise of Natural Science (New York: Cambridge University Press).

Hellsten, Laura. 2017. 'At the origins of a Western sacred dance tradition: a history in need of rewriting, in The Origins of Religion. 
Perspectives from Philosophy, Theology, and Religious Studies, eds. Hanne Applqvist and Dan-Johan Eklund, Schriften der LutherAgricola-Gesellschaft 71 (Tampere: LutherAgricola-Seura), 117-36.

Hellsten, Laura. 2021a. 'Dance as a contemplative practice: the space of distinction and union', Approaching Religion 1: 117-34, doi: $<$ https://doi.org/10.30664/ar.98065>.

Hellsten, Laura. 2021b. Through the Bone and Marrow: Re-examining Theological Encounters with Dance in Medieval Europe (Turnhout: Brepols).

Holmes, Barbara A. 2017. Joy Unspeakable: Contemplative Practices of the Black Church (Minneapolis, MN: Fortress Press).

Ideström, Jonas. 2015. Spåren i snön. Att vara kyrka i norrländska glesbygder (Skellefteå: Artos \& Norma Bokförlag).

Illman, Ruth. 2018. Music and Religious Change among Progressive Jews in London (Lanham, MD: Lexington Books).

Ingold, Tim. 2011. Being Alive: Essays on Movement, Knowledge and Description (New York: Routledge).

Israelilainen tanssi. 2021. 'Israelilainen tanssi', Israelilainen tanssi [website], <https://israelilainentanssi.wordpress.com/tanssiartikkeleita/israelilainen-tanssi/> (accessed 1.1.2022).

Jennings, Willie James. 2010. The Christian Imagination: Theology and the Origins of Race (New Haven, CT: Yale University Press).

Jennings, Willie James. 2020. After Whiteness: An Education in Belonging (Grand Rapids, MI: William B. Eerdmans Publishing Company).

Jennings, Willie James. 2021. 'Creating home: forming Christians who believe in creation and creatures, Part 2', Payton Lectures, YouTube 8.4.2021, <https://www.youtube. com/watch?v=_w6VJgZzbNI\&ab_chann el=FullerTheologicalSeminary $>$ (accessed 21.10.2021).

Karina, Lilian, and Marion Kant. 2003. Hitler's Dancers: German Modern Dance and the Third Reich (New York: Berghahn Books).

King, Karen L. 2003a. The Gospel of Mary of Magdala: Jesus and the First Woman Apostle (Santa Rosa, CA: Polebridge Press).

King, Karen L. 2003b. What is Gnosticism? (Cambridge, MA: The Belknap Press of Harvard Univeristy Press).
LaMothe, Kimerer L. 2006. Nietzsche's Dancers: Isadora Duncan, Martha Graham, and the Revaluation of Christian Values (New York: Palgrave Macmillan).

LaMothe, Kimerer L. 2018. A History of Theory and Method in the Study of Religion and Dance (Leiden: Brill).

Lloyd, Vincent. 2011. The Problem with Grace: Reconfiguring Political Theology (Stanford University Press).

Lloyd, Vincent W. 2016. Black Natural Law (New York: Oxford University Press).

Lloyd, Vincent W. 2018. In Defense of Charisma (New York: Columbia University Press).

Mahrdt, Helgard. 2019. 'To think "between past and future" and "without bannisters", lecture in 'Feminist Philosophy and the Presence of the Past' in Stockholm, March 2019.

McNeill, William H. 1997. Keeping Together in Time (Cambridge, MA: Harvard University Press).

Mead, G. R. S. 2005. The Hymn of Jesus (London: Cosimo, Inc.).

Oesterley, William Oscar Emil. 2002. Sacred Dance in the Ancient World (New York: Mineola).

Pagels, Elaine, and Karen L. King. 2007. Reading Judas: The Gospel of Judas and the Shaping of Christianity (New York: Penguin Group).

Schwan, Alexander. 2017. 'Ethos formula: liturgy and rhetorics in the work of Ted Shawn', Performance Philosophy 1: 23-39, doi: <https://doi.org/10.21476/pp.2017.31168>.

Sherman, Jane. 1989. 'The American Indian imagery of Ted Shawn', Dance Chronicle 12(3): 366-82.

Thomas, Joshua Lewis, 2021. 'When does something "belong" to a culture,' The British Journal of Aesthetics 61(3): 275-90, doi: <https:// doi.org/10.1093/aesthj/ayaao49>.

Tronca, Donatella. 2016. 'Restricted movement: dancing from late antiquity through the early middle ages', Journal of the LUCAS Graduate Conference 4: 52-63.

Tronca, Donatella. 2017. 'Dancing in ancient Christianity: initial research', in Texts, Practices and Groups. Multidisciplinary Approaches to the History of Jesus' Followers in the First Two Centuries (Turnhout: Brepols), 433-48, doi: <https://doi. org/10.1484/M.JAOC-EB.5.111715>.

Wetter, Gillis P. 1961. 'La danse rituelle dans 
l'eglise ancienne', Cahiers du Cercle Ernest Renan 29(11): 1-12.

Yarber, Angela M. 2011. Embodying the Feminine in the Dances of the World's Religions (New York: Peter Lang).

Yarber, Angela. 2013. 'Embodied activism: Israeli folk dance creating social change in the Jewish community', Implicit Religion 3: 289-300. 